\title{
TIGRIDIA PUGANA (IRIDACEAE: TIGRIDIEAE), A NEW SPECIES FROM JALISCO, MEXICO
}

\author{
Aarón RodríGueZ and Luis OrTiZ-CATEDRAL \\ Universidad de Guadalajara, Departamento de Botánica y Zoología, \\ Apdo. postal 1-139, 45101 Zapopan, Jalisco, México \\ rca08742@cucba.udg.mx
}

\begin{abstract}
Tigridia pugana (Iridaceae: Tigridieae) is described as a new species. It is characterized by producing bulbils in the axils of the cauline leaves. The flower of Tigridia pugana resembles that of T. pulchella B.L. Rob. but differs by having longer style branches that are bifid their full length, longer inner tepals and shorter ovary and fruit. So far, the new species is known only from the Sierra de La Campana and Sierra de Manantlán, in the state of Jalisco, Mexico.
\end{abstract}

Key words: Iridaceae, Jalisco, Mexico, Tigridia.

\section{RESUMEN}

Se describe Tigridia pugana. La nueva especie se caracteriza por producir bulbilos en las axilas de las hojas caulinares. La flor de T. pugana es similar a la de T. pulchella B.L. Rob. pero se diferencian de esta última por tener ramas del estilo más largas y bífidas en toda su longitud, tépalos internos más largos y ovario y fruto más pequeños. Hasta ahora, $T$. pugana sólo se conoce de las Sierras de La Campana y Manantlán, en el estado de Jalisco, México.

Palabras clave: Iridaceae, Jalisco, México, Tigridia.

Tigridia Juss. (Iridaceae: Tigridieae) is a New World genus of about 50 species. Mexico is the center of diversity with 37 known species and six subspecies. Thirty one species and all six subspecies are endemic to this country. As would be expected, the number of species is growing as new regions are explored (Espejo et al. 2001; López-Ferrari \& Espejo, 2002; Rodríguez \& Ortiz-Catedral, 2003, 2004a, 
2004b; Rodríguez \& García-Mendoza, 2004). In September of 2003, we collected a small Tigridia on the cliffs of the Sierra de la Campana, in the state of Jalisco, Mexico. The same species had been collected previously in the Sierra de Manantlán. After a detailed morphological analysis, we conclude that this is an undescribed species for which we propose the following name:

Tigridia pugana Aarón Rodr. \& L. Ortiz-Catedral, sp. nov. (Fig. 1; Figs. 2A, 2B, $2 \mathrm{C}, 2 \mathrm{D}, 3 \mathrm{~A}, 3 \mathrm{~B})$

Herba perennis, erecta, bulbosa; caules $15-35 \mathrm{~cm}$ alti, rami duo vel tres; caules in axillis foliorum bulbillis praediti; sub anthesi bracteae bulbillorum 1.8 $\mathrm{cm}$ longae et $1 \mathrm{~mm}$ latae, in fructu dilatatae, usque ad $6 \mathrm{~cm}$ longae et $3 \mathrm{~mm}$ latae; sub anthesi bulbilli ochracei, 4-5 $\mathrm{mm}$ longi et $2 \mathrm{~mm}$ lati, in fructu dilatati $8-10$ $\mathrm{mm}$ longi et $2-5 \mathrm{~mm}$ lati; flores plures, erecti, crateriformes; cupula alba, maculis marroninis ornata; tepala exteriora ovato-elliptica $1.7-2.5 \mathrm{~cm}$ longa et $0.9-1.2 \mathrm{~cm}$ lata, parte supra cupulam patentia et romarronina; tepala interiora unguiculata ad basim, hastata, reniformia, maculis marroninis ornata, 1-1.2 cm longa et $0.9-1 \mathrm{~cm}$ lata; glandula alba taeniformis, ad tepalorum partem mediam posita, 2-3 mm lata; filamenta connata, 6.5-10 mm longa; antherae oblongae ascendentes, 4.5-8 mm longae; styli ramuli 5-6 mm longi, bipartiti; sinubus styli ramorum mucro instructis; ovarium 4-7 mm longum; capsula oblongo-clavata, 1-1.6 cm longa et 4.5-5.5 mm lata; semina pyriformia, castanea, $3 \mathrm{~mm}$ longa.

Erect, bulbous perennial herb; bulb ovoid, $3-5 \mathrm{~cm}$ long, 0.5-2 $\mathrm{cm}$ wide, the outer tunics brown; flowering stem $15-35 \mathrm{~cm}$ high, with two or three branches, glabrous; basal leaves two, 30-55 cm long, 1-1.7 cm wide; cauline leaves 1 or 2, linear, the lower 20-25 cm long, 3-10 mm wide, the upper 5.5-8 cm long, 2-3 mm wide; flowering stem with bulbils in the axils of cauline leaves; bracts enclosing the bulbils $1.8 \mathrm{~cm}$ long, $1 \mathrm{~mm}$ wide at anthesis, $6 \mathrm{~cm}$ long, $3 \mathrm{~mm}$ wide in fruit; bulbils chestnut colored, 4-5 $\mathrm{mm}$ long, $2 \mathrm{~mm}$ wide at anthesis and 8-10 $\mathrm{mm}$ long, 2-5 $\mathrm{mm}$ wide in fruit; inflorescence in a rhipidium with subequal spathes, 3-6 cm long, 5$7 \mathrm{~mm}$ wide; flowers erect, crateriform; outer tepals ovate-elliptical, basally white, maroon spotted, distally dark maroon, 1.7-2.5 cm long, 0.9-1.2 cm wide; inner tepals unguiculate, hastate, reniform, spotted with dark maroon, 1-1.2 cm long, 0.9-1 cm wide; nectary forming a white band at the middle of the inner tepals, $2-3 \mathrm{~mm}$ wide; filaments connate, $6.5-10 \mathrm{~mm}$ long; anthers oblong, ascendent, $4.5-8 \mathrm{~mm}$ long; style branches 5-6 mm long, bifid in their full length with a tiny mucro inserted between 
Rodríguez y Ortiz-Catedral: Tigridia pugana, a new species from Jalisco, Mexico

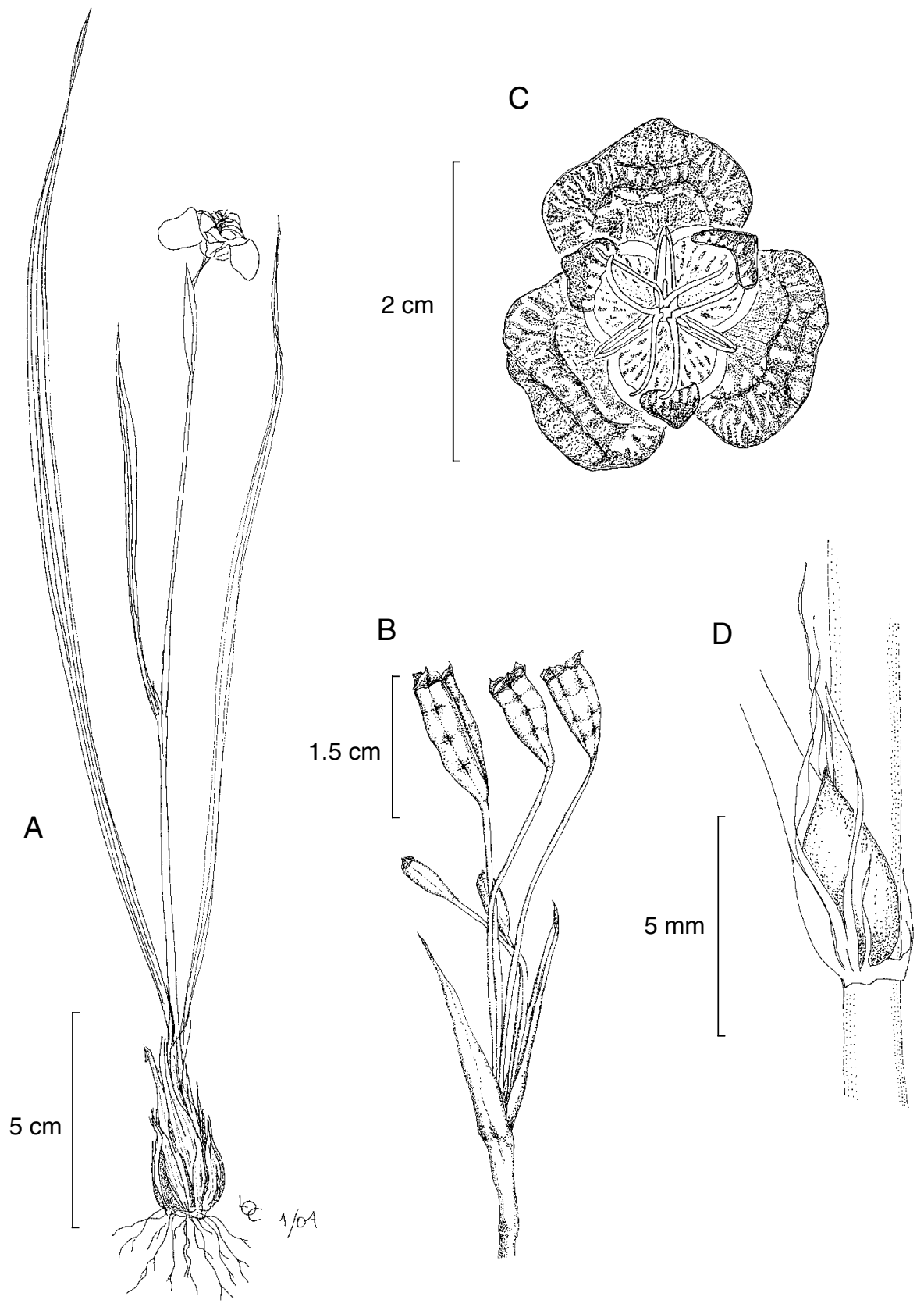

Fig. 1. Tigridia pugana. A. habit; B. fruit; C. flower, cross-view; D. bulbil in the axil of cauline leaf. 

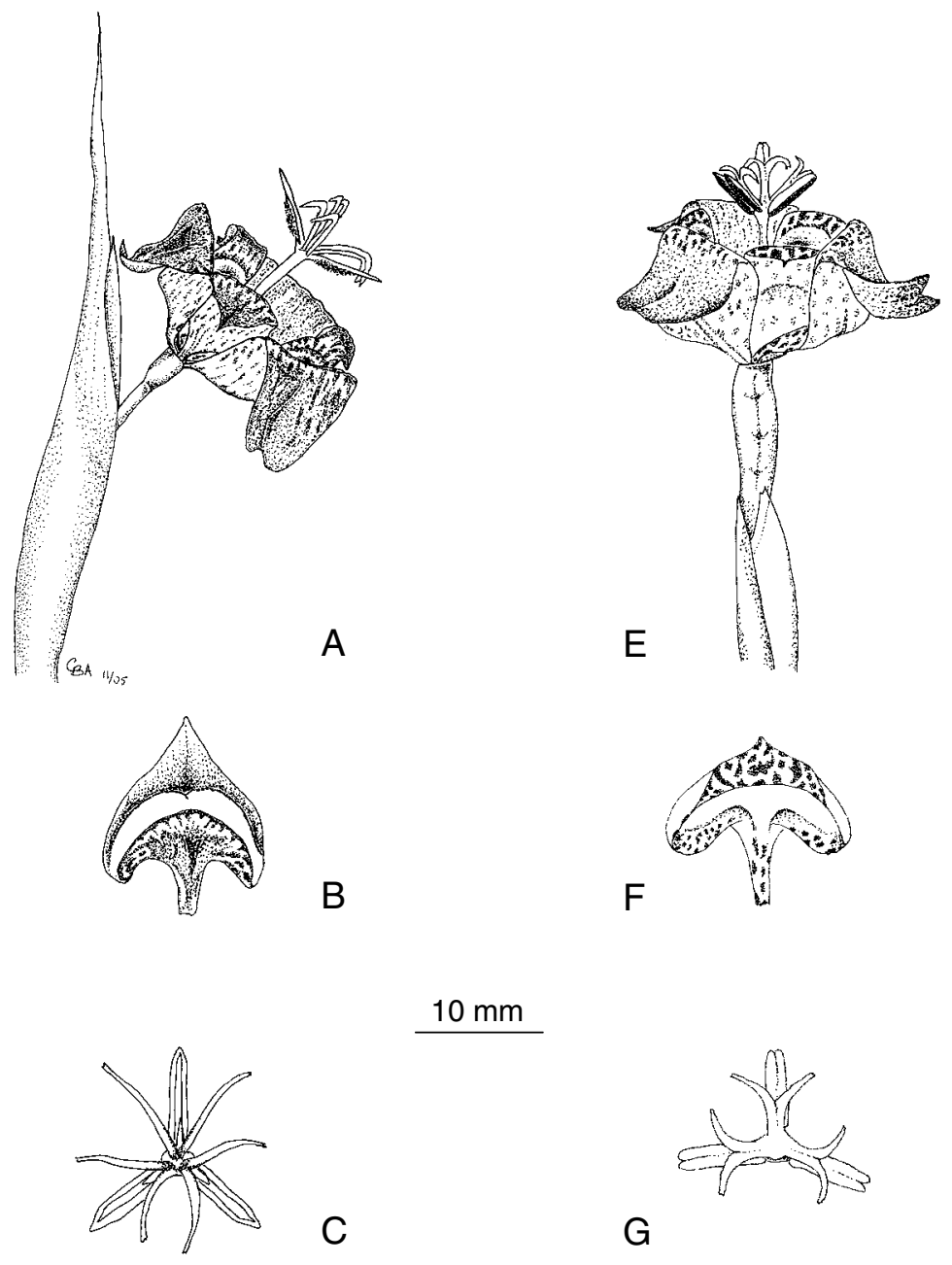

$\mathrm{F}$


Fig. 2. Tigridia pugana (A, B, C, D) and T. pulchella (E, F, G, H). The figure outlines the flower in lateral view, inner tepals, androgynoecial apparatus, and fruit, respectively. 

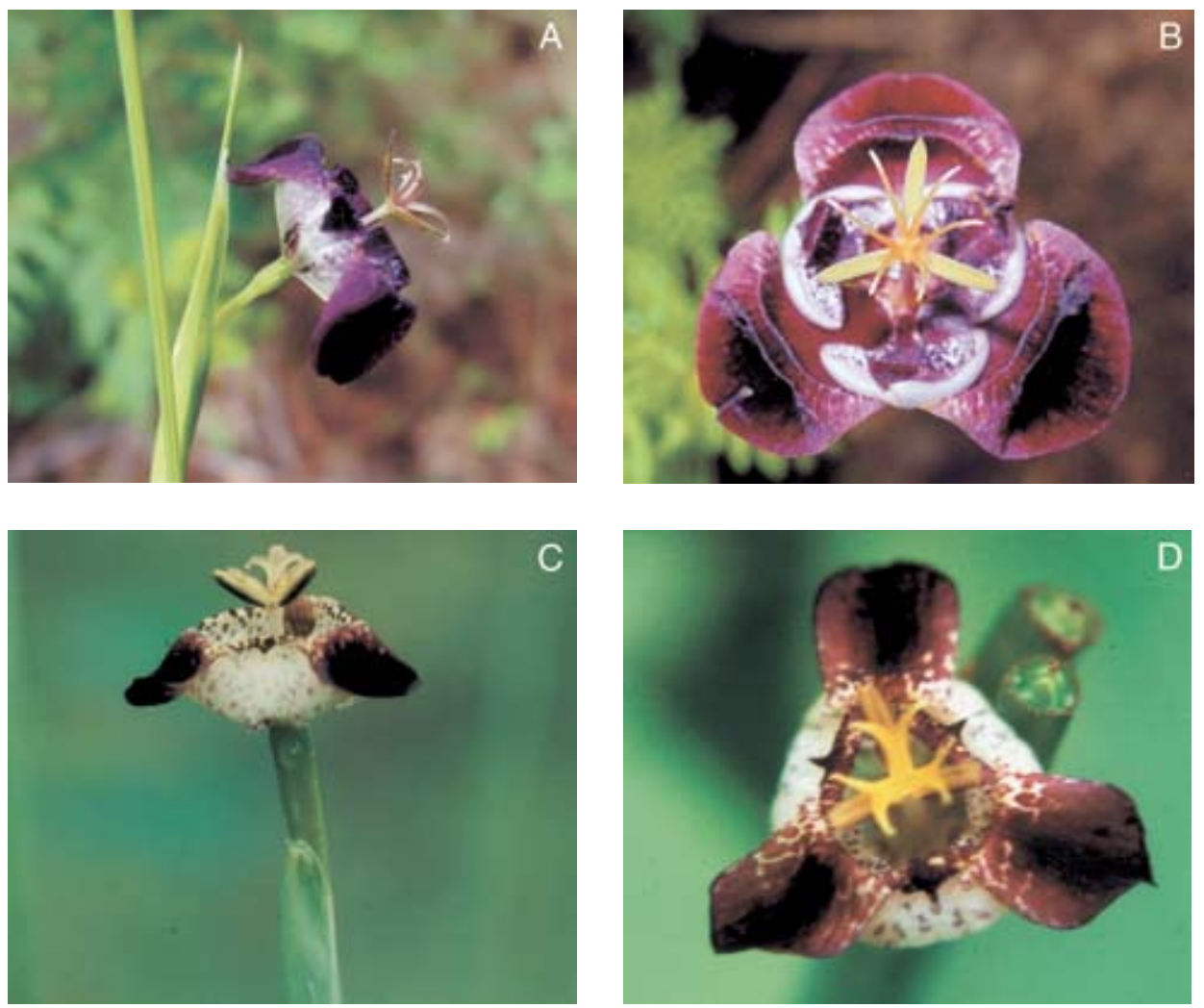

Fig. 3. Tigridia pugana (A, B) and T. pulchella (C, D). A and B are photos of the holotype by L. Ortiz-Catedral. C and D are photos by A. Rodríguez (A. Rodríguez \& A. Kennedy 4427, IBUG).

style arms; ovary oblong-clavate, 4-7 mm long; mature capsule oblong-clavate, 1$1.6 \mathrm{~cm}$ long, 4.5-5.5 mm wide; seeds pyriform, brown, $3 \mathrm{~mm}$ long; flowering in late August-September, fruiting in October-November.

Type: Mexico: Jalisco: municipio de Talpa, Sierra de la Campana, km 83 carretera Méx. 70 entre Ameca y Mascota, 1991 m s.n.m., 20²2.182' N, 104³5.596' W, 9.IX.2003, A. Rodríguez \& L. Ortiz-Catedral 3197 (holotype: IBUG; isotypes: ENCB, IEB, MEXU, NY, UAMIZ).

Additional specimens examined. MEXICO. Jalisco. municipio de Talpa, Sierra de la Campana, km 83 carretera Méx. 70 entre Ameca y Mascota, $1991 \mathrm{~m}$ 
s.n.m., $20^{\circ} 22.182^{\prime}$ N, $104^{\circ} 35.596^{\prime}$ W, 3.XI.2003, A. Rodríguez \& L. Ortiz-Catedral 3331 (IBUG); Sierra de Manantlán, Las Joyas Scientific Station, 23.VIII.1984, Suárez-Jaramillo s. $n$. (IBUG); municipio de Autlán, Puerto del Escobedo, Estación Científica Las Joyas, Sierra de Manantlán, 1970 m s.n.m., 19³5'07" N, 104¹6'25" W, 12.IX.2002, F. J. Santana-Michel et al. 11075 (ZEA).

Distribution and habitat. So far, Tigridia pugana is known only from the Sierra de la Campana and Sierra de Manantlán in the state of Jalisco. In the Sierra de la Campana, it occurs in pine-oak forest in rock crevices on cliffs. Some associates are Agave L., Cosmos Cav., Dahlia Cav., Sedum L., and mosses. In contrast, in the Sierra de Manantlán it has been collected in cloud forest with Carpinus L., Clethra L., Cornus L., Dendropanax Decne. \& Planch., and Synardisia (Mez) Lundell.

Etymology. The specific epithet honors Luz María Villarreal de Puga, pioneer of the botany in western Mexico and founder of the Herbarium at the University of Guadalajara (IBUG).

Tigridia pugana is unique by producing bulbils in the axils of the cauline leaves. All Tigridia species produce bulbs, comprising a short vertical stem, fleshy leaf bases, and dry brown to red tunics (Molseed, 1970; Rudall, 1989). Perennialism is achieved by developing a new bulb every year. On the same year, a lateral bud meristem produces leaves while the parent bulb produces the inflorescence. After dormancy, the lateral bud will be the terminal, inflorescense-producing meristem, and a new lateral bud will replace it.

Tigridia pugana is probably related to T. pulchella B.L. Rob. The floral structure and color of both species are similar. However, T. pugana is easily distinguished by having a shorter ovary, longer inner tepals and longer style arms that are bifurcate their full length (Table 1). In addition, the tepals in T. pugana do not form a pouch as in T. pulchella. The fruits of T. pugana and T. pulchella are oblong-clavate; however those of T. pugana are smaller. The nectary in $T$. pulchella covers almost the entire surface of the inner tepals (Molseed, 1970) and it is concolorous, whereas in T. pugana the nectary forms a white band in the middle of the inner tepals. Figure 2 shows a morphological comparison between the floral structures of both species. Finally, the most striking characteristic of T. pugana is that the flowering stem bears bulbils in the axils of cauline leaves, a condition not previously reported in Tigridia. 
Table 1. Morphological comparison of Tigridia pugana and T. pulchella.

\begin{tabular}{|l|l|l|}
\hline Character & \multicolumn{1}{|c|}{ T. pugana } & \multicolumn{1}{c|}{ T. pulchella } \\
\hline Outer tepal shape & ovate-elliptical & ovate \\
\hline Outer tepal length & $1.7-2.5 \mathrm{~cm}$ & $2-2.5 \mathrm{~cm}$ \\
\hline Outer tepal width & $0.9-1.2 \mathrm{~cm}$ & $1 \mathrm{~cm}$ \\
\hline Inner tepal shape & $\begin{array}{l}\text { unguiculate, hastate, } \\
\text { reniform, and not forming a } \\
\text { pouch }\end{array}$ & $\begin{array}{l}\text { long unguiculate, hastate, } \\
\text { reniform and forming a } \\
\text { pouch }\end{array}$ \\
\hline Inner tepal length & $1-1.2 \mathrm{~cm}$ & $0.6-0.7 \mathrm{~cm}$ \\
\hline Inner tepal width & $0.9-1 \mathrm{~cm}$ & $1 \mathrm{~cm}$ \\
\hline Column length & $6.5-10 \mathrm{~mm}$ & $6-9 \mathrm{~mm}$ \\
\hline Anther length & $4.5-8 \mathrm{~mm}$ & $5-6 \mathrm{~mm}$ \\
\hline Style branches length & $5-6 \mathrm{~mm}$ & $3-4 \mathrm{~mm}$ \\
\hline Styles branches shape & bifurcate all their length & bifurcate half their length \\
\hline Nectary bands width & $2-3 \mathrm{~mm}$ & 4 mm \\
\hline Nectary color & white & concolorous \\
\hline Ovary length & $4-7 \mathrm{~mm}$ & $10-12 \mathrm{~mm}$ \\
\hline Capsule length & $1-1.6 \mathrm{~cm}$ & $2-4.5 \mathrm{~cm}$ \\
\hline
\end{tabular}

\section{ACKNOWLEDGMENTS}

We thank Roberto González Tamayo for his suggestions to the manuscript and José Suárez Jaramillo for sharing the information about the material from Sierra de Manantlán. The illustrations were made by Luis Ortiz-Catedral and Christian Briseño-Avena.

\section{LITERATURE CITED}

Espejo, A., A. R. López-Ferrari, J. Ceja \& A. Cholewa. 2001. Two new species of Mexican Iridaceae. Acta Bot. Mex. 55: 21-27.

López-Ferrari, A. R. \& A. Espejo. 2002. Tigridia potosina (Iridaceae: Tigridieae) una nueva especie de la Sierra de Álvarez, San Luis Potosí, México. Acta Bot. Mex. 61: 35-40.

Molseed, E. 1970. The genus Tigridia (Iridaceae) of Mexico and Central America. Univ. California Publ. Bot. 54: 1-113. 
Rodríguez, A. \& L. Ortiz-Catedral. 2003. Tigridia gracielae (Tigridieae: Iridaceae), a new species from Mexico. Acta Bot. Mex. 64: 31-36.

Rodríguez, A. \& L. Ortiz-Catedral. 2004a. Tigridia rzedowskiana (Tigridieae: Iridaceae), una nueva especie del estado de Querétaro, México. Acta Bot. Mex. 71: 53-59.

Rodríguez, A. \& L. Ortiz-Catedral. 2004b. Tigridia suarezii (Iridaceae, Tigridieae), a new species from Jalisco, Mexico. Novon 15: 354-357.

Rodríguez, A. \& A. García-Mendoza. 2004. Tigridia amatlanensis (Tigridieae: Iridaceae), a new species from Oaxaca, Mexico. Brittonia 56: 128-131.

Rudall, P. 1989. Stem thickening growth in bulbous Iridaceae. Bot. Gaz. 150: 132-138.

Recibido en noviembre de 2005.

Aceptado en abril de 2006. 